\title{
Synchronous pyoderma gangrenosum and inflammatory bowel disease, healing after total proctocolectomy
}

\author{
Pioderma gangrenoso associado a doença inflamatória intestinal, com \\ resolução após proctocolectomia total
}

\author{
Pedro Andrade ${ }^{1}$ \\ Américo Figueiredo ${ }^{3}$
}

\author{
Maria Manuel Brites ${ }^{2}$
}

\begin{abstract}
We present a female patient observed with painful violaceous plaques with central bullae and pustules on the lower limbs, rapidly transformed into ulcers, associated with bloody diarrhea, recurrent oral erosions and hyperthermia in the previous 3 months. Cutaneous biopsy was consistent with pyoderma gangrenosum, and intestinal diagnostic procedures revealed a non-classifiable inflammatory bowel disease with high $\mathrm{x}$-ANCA titers. Soon after admission the patient was submitted to total proctocolectomy following colonic perforation. Complete ulcer healing occurred three months after surgery, without recurrence. Pyoderma gangrenosum is a rare dermatosis frequently associated with inflammatory bowel disease. This case is particularly interesting for the synchronic clinical presentation of cutaneous and intestinal diseases, but also for the prompt regression of the former after total proctocolectomy.

Keywords: Colectomy; Inflammatory bowel diseases; Pyoderma gangrenosum
\end{abstract}

Resumo: Apresentamos uma paciente do sexo feminino observada com múltiplas placas violáceas dolorosas dos membros inferiores, com bolhas e pústulas evoluindo rapidamente para lesões ulceradas, surgindo no contexto de diarreia sanguinolenta, erosões orais recorrentes e febre com três meses de evolução. A biópsia cutânea foi compatível com pioderma gangrenoso; o estudo complementar revelou doença inflamatória intestinal inclassificável com títulos elevados de x-ANCA. Após perfuração cólica, a doente foi submetida a proctocolectomia total, com rápida cicatrização das lesões cutâneas ulceradas em três meses, sem recorrência. O pioderma gangrenoso é uma dermatose rara frequentemente associada a doença inflamatória intestinal. É interessante verificar neste caso a apresentação clínica sincrónica das doenças cutânea e intestinal, bem como a rápida resolução da primeira após proctocolectomia total.

Palavras-chave: Colectomia; Doenças inflamatórias intestinais; Pioderma gangrenoso

\section{INTRODUCTION}

Pyoderma gangrenosum is a rare neutrophilic dermatosis of unclear etiopathogenesis which is frequently associated with systemic disease, particularly inflammatory bowel disease, myeloproliferative disorders or malignancy. ${ }^{1,2,3}$ Its course and prognosis are highly unpredictable, as many different topical and systemic treatments have been proposed, with variable results. ${ }^{1,2}$

\section{CASE REPORT}

We present a 67-year-old female patient obser- ved with multiple painful violaceous plaques with central flaccid bullae and pustules on distal lower limbs, rapidly transforming into deep ulcers with infiltrated erythemato-violaceous undermined borders and centrifugal progression (Figures 1 and 2). This patient reported recurrent mucous bloody diarrhea, diffuse abdominal pain, painful oral ulcers, hyperthermia, asthenia, anorexia and significant weight loss in the previous three months, of unknown nature. Histopathologic skin examination

Received on 24.06.2011

Approved by the Advisory Board and accepted for publication on 14.07.2011

* Study carried out at the Teaching Hospitals of University of Coimbra (Universidade de Coimbra, EPE Serviço de Dermatologia e Venereologia) - Coimbra, Portugal. Conflict of interest: None

Financial funding: None

M.D - Intern of Dermatology and Venereology - Teaching Hospitals of University of Coimbra (Universidade de Coimbra, EPE Serviço de Dermatologia e Venereologia) - Coimbra, Portugal.

M.D - Specialist in Dermatology and Venereology - Hospital Assistant - Teaching Hospitals of University of Coimbra (Universidade de Coimbra, EPE Serviço de Dermatologia e Venereologia) - Coimbra, Portugal.

Ph.D - Professor-doctor - Specialist in Dermatology and Venereology - Director of the Dermatology and Venereology Service - Teaching Hospitals of University of Coimbra (Serviço de Dermatologia e Venereologia - Hospitais da Universidade de Coimbra, EPE Serviço de Dermatologia - Coimbra, Portugal.

(C)2012 by Anais Brasileiros de Dermatologia 


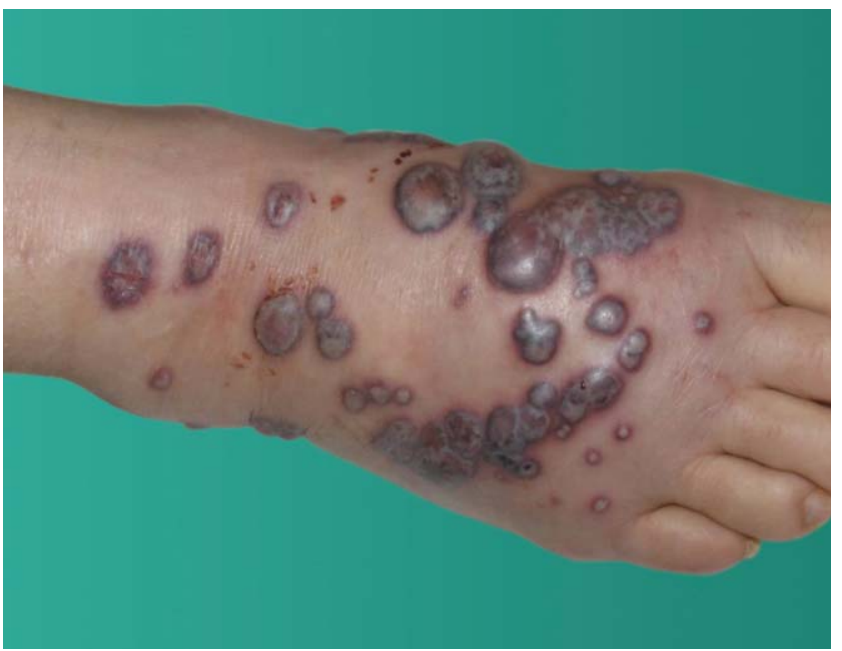

FIGURE 1: Multiple painful violaceous plaques with bullae and pustules on the dorsum of the right foot

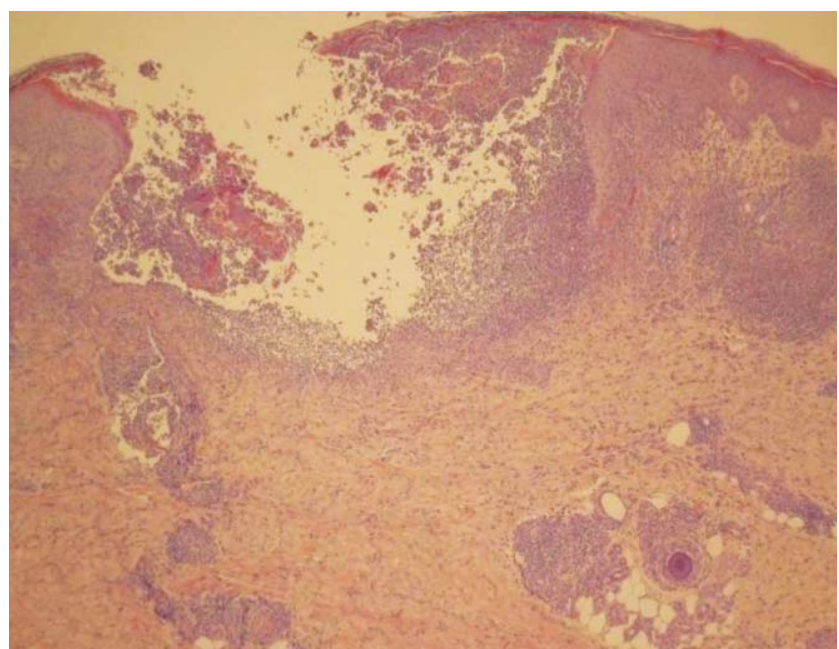

Figure 3: Large intraepidermic pustule and dense karyoclastic neutrophilic dermal infiltrate without vasculitis consistent with pyoderma gangrenosum, revealed by histopathologic analysis of the skin $(\mathrm{H} \& \mathrm{E}, 40 \mathrm{x})$

revealed an intra-epidermic pustule surrounded by a dense neutrophilic dermal infiltrate, without evidences of vasculopathy, supporting the clinical diagnosis of pyoderma gangrenosum (Figures 3 and 4). Apart from high erythrocyte sedimentation rate $\left(83 \mathrm{~mm}, 1^{\text {st }}\right.$ hour), C-reactive protein $(190 \mathrm{mg} / \mathrm{l})$ and leukocytosis (WBC $13.400 \times 10^{9} / \mathrm{L}$ ) with neutrophilia $(83,2 \%)$, high titers of serum antineutrophil cytoplasmic antibodies (x-ANCA) were also detected. HIV infection was excluded by ELISA serology. Subtotal colonoscopy showed severe rectocolitis with extensive mucosal ulceration, clinically and histologically consistent with unspecific inflammatory bowel disease. No other significant analytical changes were detected, including microbiologic analysis of faecal samples and serum anti-Saccharomyces cerevisiae antibo-

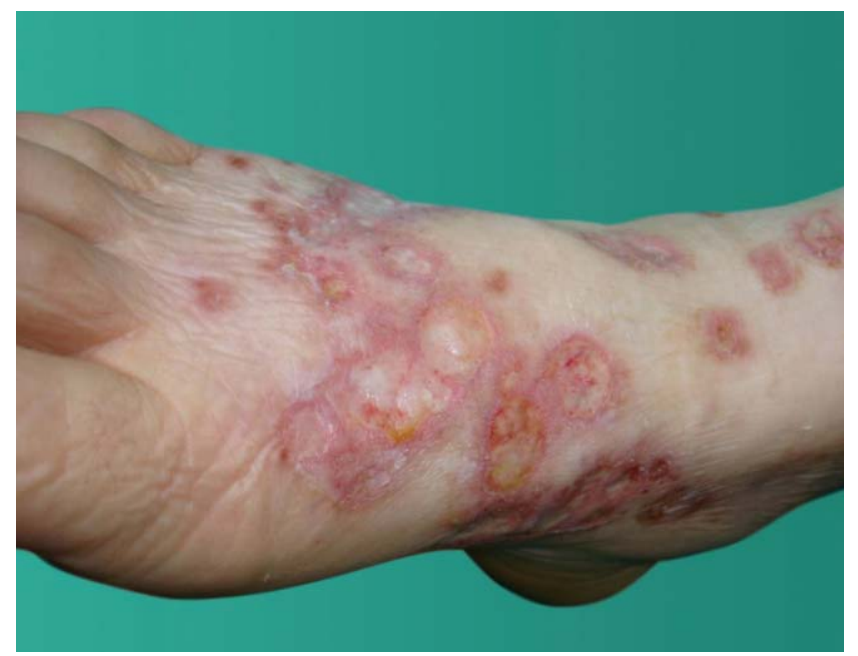

Figure 2: Painful deep ulcers with undermined violaceous borders and centrifugal progression dies (ASCA). Cytomegalovirus (CMV) infection was excluded by negative serology and colonic histological analysis. Additionally, esophagogastroduodenoscopy did not reveal upper gastrointestinal lesions. Treatment with oral mesalazin, ciprofloxacin, metronidazol and methylprednisolone $(1 \mathrm{mg} / \mathrm{kg})$ was performed for 10 days, with no significant improvement of both intestinal and cutaneous diseases. In this context, a second diagnostic colonoscopy was performed, resulting in colonic perforation with peritoneal abscedation. Therefore, the patient was submitted to emergency left colectomy, and later to total proctocolectomy due to early postsurgical complications. Colonic macroscopic examination revealed a continuous transmural chronic inflammation with multiple deep mucosal ulcers; on histopathologic

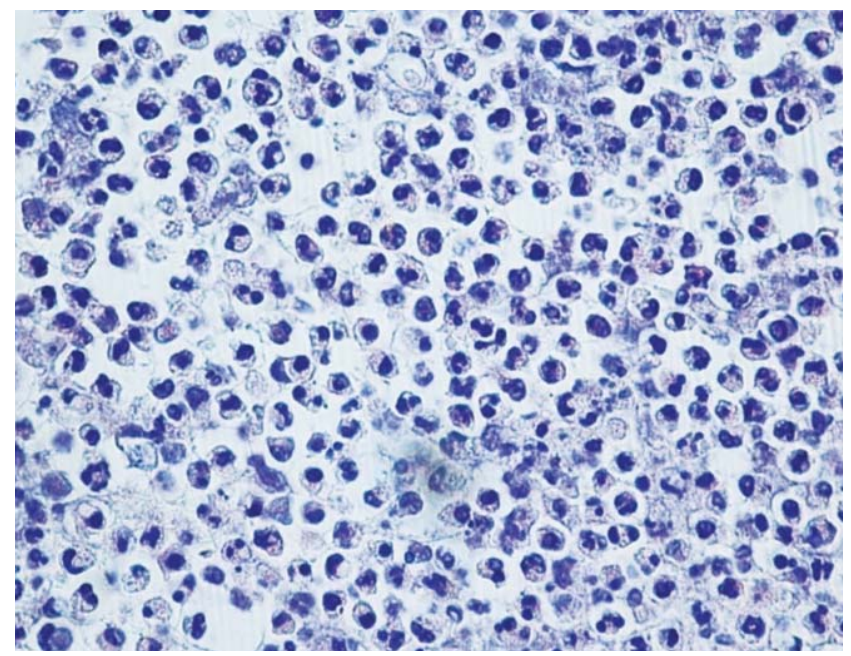

Figure 4: Detail of the dense neutrophilic dermal infiltrate revealed by histopathologic analysis of the skin (H\&E, 400x) 


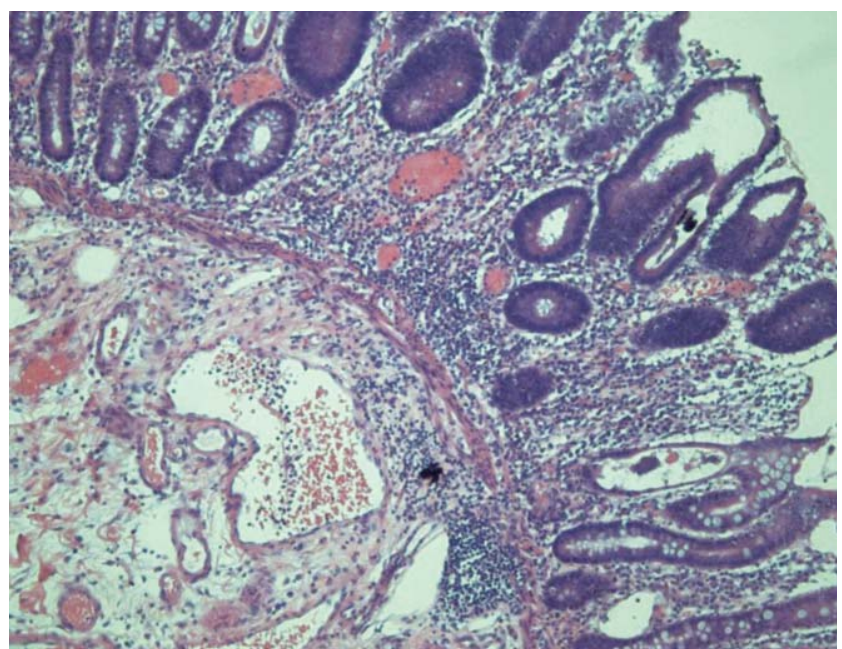

FIGURE 5: Colonic histopathologic analysis, revealing a dense neutrophilic infiltrate with extensive mucosal ulceration and nonspecific granulation tissue, consistent with non-classifiable inflammatory bowel disease. No evidences of epithelial granulomas, dysplasia or CMV infection were observed (H\&E, 100x)

examination, an extensive neutrophilic inflammatory infiltrate was observed, with important mucosal ulceration, lacking epithelial granulomas, dysplasia or nuclear CMV inclusions - in the context of acute peritonitis and lacking specific classification criteria, it was still not possible to classify the diagnosed inflammatory bowel disease (Figure 5).

Oral steroids were suspended immediately after surgery, and local occlusive topical treatment with clobetasol propionate ointment $(0.05 \%)$ was started. Complete ulcer healing was observed within three months after abdominal surgery, and no recurrence was detected in the following 2 years (Figure 6). Pathergy phenomena were also not reported.

\section{REFERENCES}

1. Ruocco E, Sangiuliano S, Gravina AG, Miranda A, Nicoletti G. Pyoderma gangrenosum: an updated review. J Eur Acad Dermatol Venereol. 2009;23:1008-17.

2. Wollina U. Pyoderma gangrenosum - a review. Orphanet J Rare Dis. 2007;2:19.

3. Santos M, Talhari C, Rabelo RF, Schettini AP, Chirano CA, Talhari S. Pyoderma gangrenosum: a clinical manifestation of difficult diagnosis. An Bras Dermatol. 2011;86:153-6.

4. Cohen PR. Neutrophilic dermatoses: a review of current treatment options. Am J Clin Dermatol. 2009;10:301-12.

5. Mir-Madjlessi SH, Taylor JS, Farmer RG. Clinical course and evolution of erythema nodosum and pyoderma gangrenosum in chronic ulcerative colitis. Am J Gastroenterol. 1985;80:615-20.

6. Rimbaud P, Maynadier J. [Pyoderma gangrenosum and hemorrhagic rectocolitis. Rapid cure after colectomy]. Bull Soc Fr Dermatol Syphiligr. 1967;74:482-4

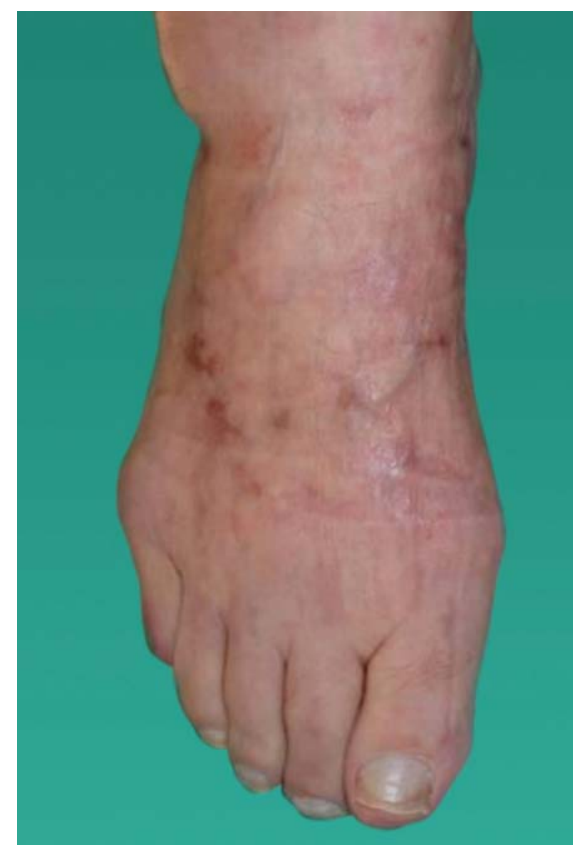

Figure 6: Complete ulcer healing three months after proctocolectomy

\section{DISCUSSION}

The relevance of this case is supported not only by the synergic evolution of severe pyoderma gangrenosum and inflammatory bowel disease, but also by the prompt regression of the former after proctocolectomy. The synchronic clinical presentation of both diseases is particularly interesting, corroborating a clear connection between them. Although there is some evidence showing good results in mild cutaneous disease with topical steroids in monotherapy, in most cases aggressive medical therapies are required and often insufficient. ${ }_{1,2,4} \mathrm{~A}$ good control of the underlying bowel disease is clearly helpful, and radical intestinal surgical treatment has been previously described as effective for associated pyoderma gangrenosum. ${ }^{1,2,5,6} \mathrm{D}$

How to cite this article: Andrade P, Brites MM, Figueiredo A. Synchronous Pyoderma Gangrenosum and Inflammatory Bowel Disease, healing after total proctocolectomy. An Bras Dermatol. 2012;87(4):637-9. 